Diabetologia 10, 337-344 (1974)

(C) by Springer-Verlag 1974

\title{
Monolayer Cell Culture of Adult Rat Islets of Langerhans**
}

\author{
M. Kostianovsky, M. L. MoDaniel, M.F. Still, R.C. Codilla, and P.E. Lacy \\ Veterans Administration Hospital, St. Louis, Missouri and Department of Pathology, Washington University, St. \\ Louis, Missouri, U.S.A.
}

Received: December 21, 1973, and in revised form: April 16, 1974

\begin{abstract}
Summary. This report describes a method for monolayer cell culture of adult rat pancreatic islets. In this procedure, the isolated islets of Langerhans were enzymatically dispersed and subsequently cultured for 2 to 3 weeks. Enhanced secretion of insulin was present over the basal secretion rate when the cultures were exposed to a high glucose concentration alone or to a combination of glucose, theophylline and glucagon. The ultrastructural
\end{abstract}

studies of the beta cells in culture demonstrated preservation of their morphological characteristies throughout the culture periods.

Key words: Monolayer cell culture, trypsin digestion, insulin secretion, glucose, theophylline, glucagon, ultrastructural studies, microtubules, microfilaments.
In the last decade the study of the endocrine pancreas in vitro and, more recently, the application of tissue culture techniques has attracted a great number of investigators. Since much of the knowledge of the mechanisms of insulin release has been obtained from in vitro preparations, the study of isolated pancreatic islets maintained in long term culture appears very promising.

Two basically different approaches have been used in tissue culture preparations. One involves the culture of pancreatic fetal explants $[16,18,25,32]$, or enzymatically dispersed neonatal pancreas, which contain both acinar and endocrine tissue $[10,17,21,27]$. In the fetal pancreas preparations, the B-cells have been shown to be immature and glucose insensitive [19, 20]. B-cells obtained from neonatal pancreas responded to insulinotropic agents and showed by electron microscopy progressive B-cell granulation and/or in vitro maturation as well as dedifferentiation of the acinar tissue [26].

The second experimental model uses the organ culture technique, with pancreatic islets isolated from adult pancreas of rats or other rodents $[1,2,3,11,23$, $24,28,33]$. This procedure has been useful in providing a new experimental tool for the study of adult Bcell behaviour in long term culture, with preservation of the ultrastructural features for up to 3 weeks [12]. This technique is also being used for transplantation of isolated islets after maintenance in culture for varying periods of time. Nevertheless, the organ culture technique, utilizing isolated pancreatic islets, has the following disadvantages: a) A true mono-layer is formed only at the periphery of the primary explant and therefore limits the observations throughout the culture period. b) The environment of each cell varies depending upon its position in the tissue mass.

In a preliminary report [13] we described a tech-

* Supported by V.A. Grant MRIS 4689 and USPHS Grant AM01226 nique for monolayer preparation of adult pancreatic islets. This procedure consisted of the disruption of the capsule and cellular organization of the isolated pancreatic islets by trypsin digestion. The purpose of this paper is to describe the application of this technique in maintaining in tissue culture a monolayer preparation obtained from adult rat pancreatic islets. We observed ultrastructural preservation of the cellular organelles as well as predictable physiological responses of the B-cells to the action of insulinotropic agents.

\section{Material and Methods}

\section{a) Tissue Preparation}

Four to eight male albino rats weighing 300 to $400 \mathrm{~g}$ were used in each experiment. The islets were isolated aseptically using the collagenase technique [15]. In order to obtain appropriate number of islets in a short time, Ficoll gradients were used [30], instead of the sedimentation procedure of the collagenase technique. The Ficoll, previously lyophilized and dialyzed, was prepared in concentrations of $25 \%, 23 \%$, $20.5 \%$ and $11 \%(\mathrm{w} / \mathrm{v})$ in Hank's buffer solutions. Four $\mathrm{ml}$ of the $25 \%$ Ficoll and the collagenized and washed pancreatic tissue was thoroughly mixed, using a vortex mixer. The different Ficoll concentrations ( $2 \mathrm{ml}$ of each) were carefully layered in a centrifuge tube, which was centrifuged at $900 \mathrm{~g}$ for $20^{\prime}$. The acinar tissue remained at the bottom of the tube and the islets were present at the $20.5 \%$ level and at the interface between the $20.5 \%$ and $23 \%$ level. The $20.5 \%$ layer plus the interface layer, containing an average of 900 to 1200 islets (150 to 200 islets per rat), was pipetted out, washed in Hank's buffer solution and transferred to a $3 \mathrm{ml}$ prewarmed $\mathrm{Ca}^{++}, \mathrm{Mg}^{++}$-free buffer, containing $0.25 \%$ trypsin (Difco trypsin). The isolated islets were then disrupted by gently pipetting for $2^{\prime}$ at $37^{\circ} \mathrm{C}$. The time of trypsin digestion was standardized at $2^{\prime}$ yield- 
ing small clumps of pancreatic islet cells. Some experiments were carried out with $5^{\prime}$ trypsinization, which produced a single cell suspension. After the $2^{\prime}$ trypsin treatment the tissue was washed twice in tissue culture medium and the pellet resuspended in the final culture medium. No cellular quantitative studies were performed and each dish served as its own control (see stimulation).

\section{b) Tissue Culture Conditions}

The medium used was CMRL 1066 (GIBCO), with the addition of $15 \%$ fetal calf serum, penicillin 100 units per $\mathrm{ml}$, streptomycin sulfate $100 \mu \mathrm{g} / \mathrm{ml}$, gluta. mine $2 \mathrm{mM}$, vitamins and also $100 \mathrm{mg} \%$ of glucose, except during the stimulation periods, as stated below. The tissue was planted in falcon petri dishes containing $0.9 \mathrm{ml}$ of medium; they were maintained at $37^{\circ} \mathrm{C}$ in a humidified atmosphere of $95 \%$ air $5 \% \mathrm{CO}_{2}$. The tissue was kept at $37^{\circ} \mathrm{C}$ for 15 days to 4 weeks, changing the medium twice a week.

\section{c) Light and Electron Microscopic Preparations}

Exporiments which were to be processed for light microscopy were planted in Sykes-Moore chambers. After the desired time, $(15-20$ days $)$ in culture, the bottom cover slip, with the attached cells in situ, was fixed in Bouin's fixative and directly stained with hematoxylin and eosin or aldehyde fuchsin $[8,31]$. At different times during the culture period, as well as after the exposure to insulinotropic agents, the tissue was fixed in situ for electron microscopic observations. All the steps of fixation, dehydration and embedding were accomplished without detaching the cells from the culture dishes. The cells were fixed in $4 \%$ cacodylate buffered glutaraldehyde, $\mathrm{pH}$ 7.3, post fixed in osmium tetroxide and dehydrated with ethanol and hydroxymethyl metacrylate and covered with a thin layer of Epon 812 embedding media. The polymerization was carried out at $60^{\circ} \mathrm{C}$ for $5 \mathrm{~h}$. The cells embedded in the epon were detached from the bottom of the petri dish by a gentle prcedure, applying a twisting rotary force to the epon sheet [29].

\section{d) Stimulation and Insulin Release}

The tissue was maintained in culture for 4 to 5 days to allow firm attachment of the cells to the bottom of the petri dishes. Prior to the stimulation experiments, the culture medium was removed and the tissue gently washed 3 times with tissue culture medium containing $30 \mathrm{mg} \%$ glucose. The cells were exposed to the same medium containing $30 \mathrm{mg} \%$ glucose for $2 \mathrm{~h}$, the supernatant removed and the tissue washed again. The cells were then exposed to medium containing $300 \mathrm{mg} \%$ glucose for the same period of time. In order to obtain maximal insulin release, some experiments were performed in which the cultured cells were stimulated by a combination of high glucose (300 $\mathrm{mg} \%$ ), theophylline $\left(10^{-3} \mathrm{M}\right)$, and glucagon $(10 \mu \mathrm{g} / \mathrm{ml})$. The supernatants of these experiments were stored at $-20^{\circ} \mathrm{C}$ and the insulin content assayed using the technique described by Wright et al. [34]. With this procedure, it was possible to compare the amount of insulin released from the same dish on the same day ander a variety of experimental conditions.

\section{Results}

\section{Morphology}

a) Light Microscopy. Viewed under the inverted microscope immediately after being separated and planted, the tissue consisted of small clusters of 10 to 25 cells having a round outer contour and containing abundant cytoplasm, which was faintly granular (Fig. 1). After 4 to 5 days in culture they attached to the bottom of the dish, changing their shape and becoming flattened cells with thin, cytoplasmic projections (Fig. 2). Very few cell aggregates and isolated cells remained free-floating in the medium. These unattached cells, which showed signs of degeneration, were removed during the first change of medium. In most dishes, by the 4 th to 5 th day in culture, elongated, fibroblastoid cells appeared at the periphery of the epithelial clusters. Light microscopic studies after 15 days in culture showed the monolayers of pancreatic islet cells attached to the cover slip (Fig. 3) and 80\% of the cells which contained normal granulation gave a positive reaction with aldehyde fuchsin stain.

b) Electron Microscopy. Control electron microscopy of the cells immediately after trypsinization showed a general preservation of the ultrastructure, with very few cells displaying necrosis or signs of injury. By varying the time of trypsin treatment, different preparations were obtained (Fig. 4). Using $5^{\prime}$ trypsinization a single cell suspension was recovered which retarded the attachment of the cells. Blebbing was observed in some instances (Fig. 4 left), although it was not known if it was secondary to trypsin digestion or to other factors.

On the other hand, with $2^{\prime}$ trypsinization, the tissue which was removed consisted of clumps and small cell aggregates. The latter time was used in all the experiments presented in this report. The general preservation of ultrastructure was excellent throughout the life-span of the culture. Signs of injury were seen mainly in the first few days of culture.

Fig. 1. Phase micrograph of living cells immediately after being planted, illustrating the round appearance and cytoplasmic granularity. $\times 400$

Fig. 2. Phase micrograph of the living cells showing the flattened appearance and cytoplasmic projections of the attached epithelial clumps. Five days culture $\times 400$

Fig. 3. Light micrograph of Aldehyde Fuchsin stained cells showing clumps of epithelial cells with positive reaction (arrows) in many cells. Fifteen days in culture $\times \mathbf{3 0 0}$ 

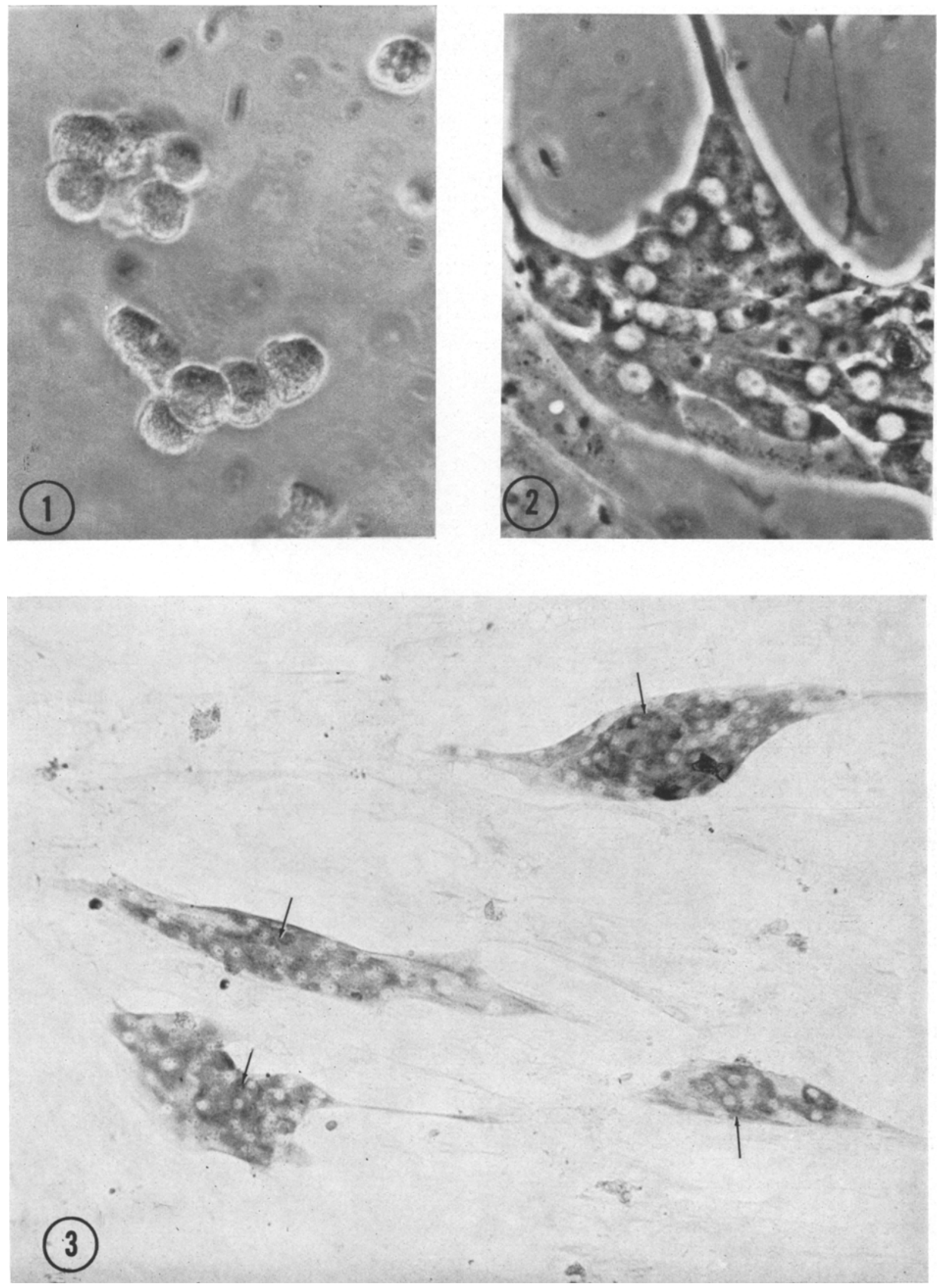
The examination of multiple specimens revealed that the ultrastructural appearance of the cultures was similar to the normal pancreas, except for the form of the cells and an increased amount of filaments, microfilaments and microtubules present in their cytoplasm. Most of the cells displayed an elongated appearance, with pronounced microvilli formations, which formed fingerlike projections at the cell periphery (Fig. 5). The cells were attached by interdigitated projections (Fig. 5). Desmosomes were present in some other areas (Fig. 6). Very often stacks of parallel membranes were present forming a prominent golgi complex, as well as prominent rough endoplasmic reticulum. The cell granularity was normal, with prevailing mature type of granularity and frequent crystalline appearance of the granule (Fig. 7). The cells were permeated by microfilaments as well as microtubules, which appeared. to run parallel to one another as well as parallel to the cell plane of attachment to the dish. In the cytoplasmic projections the microtubules were very often the prevailing organelle. Bundles of microfilaments were seen perinuclearly, located similarly to those described as "stress fibers" in cultured fibroblasts [4]. In addition, bundles of microfilaments beneath the plasma membrane were also seen, intermingled with scattered microtubules. In some instances, the microtubules were closely related to the mitochondria as well as the membranous sac encasing the secretory granules, but no definite connection between them was found. Microtubules and microfilaments were in close apposition and were more marked in the outer rim of the cytoplasm, where they were concentrated. Lysosomes, phagocytic vacuoles, myelin figures, lipoid droplets, as well as polyribosomes, were distributed throughout the cytoplasm. B-cells in mitosis were infrequently seen. In addition to B-cells, scattered A-cells and Dcells were present and also cells resembling the socalled serotonin secreting cells (Fig. 8). Fibroblastoid cells were present surrounding the epithelial clusters (Fig. 7), showing cisterna of rough surfaced endoplasmic reticulum and small vesicles. Prominent aggregates of filaments filled the periphery of the cytoplasm (Fig. 7). Fibroblastoid cells were also present, containing lipoid droplets. The predominant cellular epithelial component of the cultures were the B-cells which maintained their normal granularity throughout the culture period, showing no distinct ultrastructural differences when the culture was exposed to either low or high glucose concentrations.

\section{Functional Studies - Insulin Release}

Fig. 9 summarizes the results of experiments studying the effect of glucose on insulin release from the pancreatic cells in monolayer culture. In these experiments, a basal rate of insulin release was established by exposing the culture to $30 \mathrm{mg} \%$ glucose for $2 \mathrm{~h}$ of incubation. Increasing the glucose concentration from $30 \mathrm{mg} \%$ to $300 \mathrm{mg} \%$ over the same time period. markedly stimulated insulin release into the incubation medium. The amount of insulin released over a $2 \mathrm{~h}$ period at $300 \mathrm{mg} \%$ glucose, above the basal rate obtained at $30 \mathrm{mg} \%$ glucose, was $2.1 \pm 0.3,1.4 \pm 0.4$ and $2.5 \pm 0.5 \mathrm{mU}$ insulin/culture respectively at day 7,9 , and 11-12. Although the basal rate of insulin release tended to increase throughout the culture period, the response to insulin stimulating levels of glucose appeared very similar. Insulin stimulation experiments using a combination of glucose $(300 \mathrm{mg} \%)$, theophylline $\left(10^{-3} \mathrm{M}\right)$, and glucagon $(10 \mu \mathrm{g} / \mathrm{ml})$ have been studied over a shorter incubation period of $30 \mathrm{~min}$, and an enhancement of insulin release was observed over basal levels.

\section{Discussion}

The present technique clearly demonstrated the ability of enzymatically dispersed isolated cells obtained from adult pancreatic rat islets to adjust to in vitro culture conditions. Phase microscopy of the living cells as well as light microscopic studies revealed clusters of epithelial cells forming monolayers. Special staining of these epithelial clusters showed that they are composed of approximately $80 \%$ of B-cells when fixed and processed after 2 weeks in culture.

The epthelial aggregates were surrounded by a ring of fibroblastoid cells, which increased in number throughout the culture period. No subculture nor decantation techniques were used in this study, since the dishes were maintained for a period of 2 or 3 weeks, and at this time no harmful interference nor overgrowth of fibroblasts was observed. Electron microscopic studies revealed elongated B-cells with normal granulation and preserved ultrastructural appearance. They showed an increased amount of microfilaments and microtubules as compared. with the non-cultured Bcells obtained from pancreatic islets. It appears from other reports [7] that the abundance of these organelles is one of the ultrastructural characteristics of cultured cells in monolayers. This may be due to the stretching conditions of attachment of the cells to the substratum as well as the presence of different forces exerted on the monolayer cells, compared with in vivo cells [9].

Besides B-cells, small numbers of A- and D-cells, as well as cells resembling the so-called serotonin secreting cells were also evident. The B-cells were the prevailing epithelial component throughout the culture period. Mitoses was observed infrequently.

Studies on insulin secretion demonstrated the functional eapacity of the adult B-cells in culture to respond to the influence of high glucose concentration alone, and in combination with glucagon and theophylline to potentiate insulin release. Lacy et al. [14], using short term incubation of isolated Langerhans islets, demonstrated the potentiating effect of these substances on insulin release in vitro.

Fetal and neonatal pancreas have been used as the source of endocrine pancreatic monolayers $[17,21]$. 


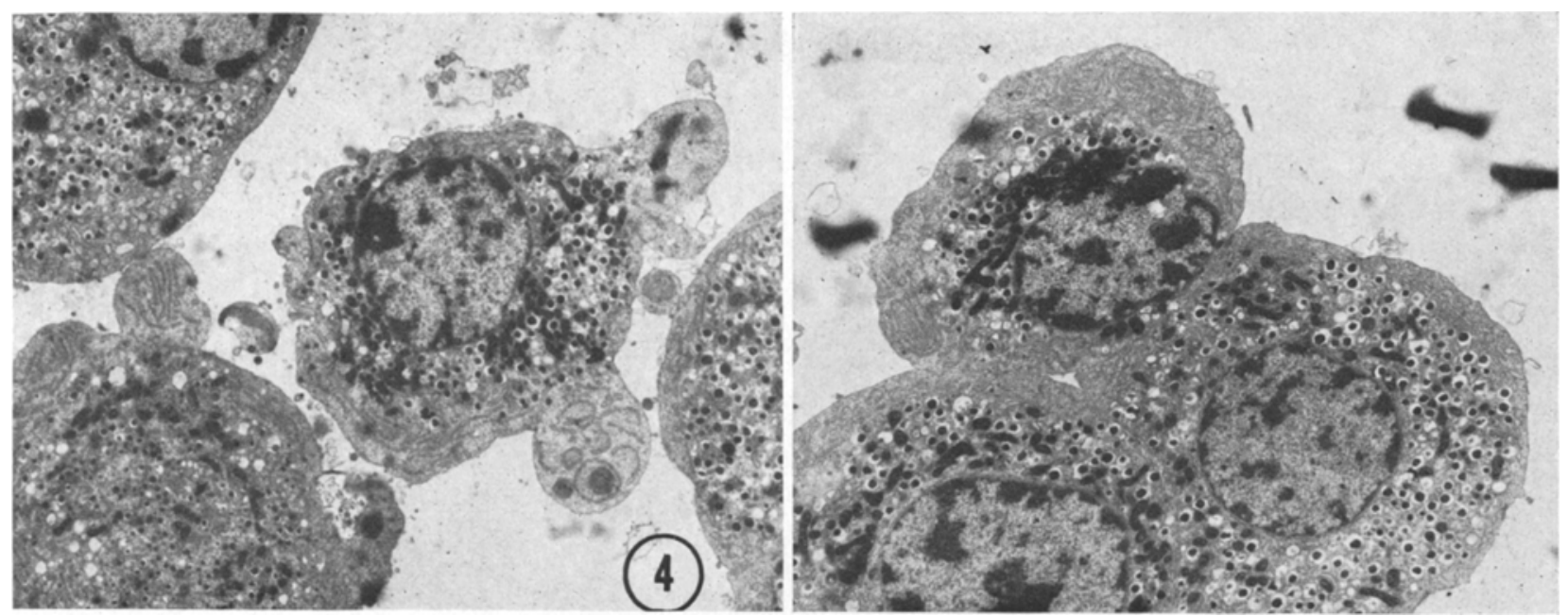

Fig. 4. Cells immediately after trypsin treatment. Left: $5^{\prime}$ trypsin exposure produced single cell suspension $\times 5000$. Blebbing was sometimes present. Right: After $2^{\prime}$ trypsinization small cell aggregates were recovered $\times 6000$

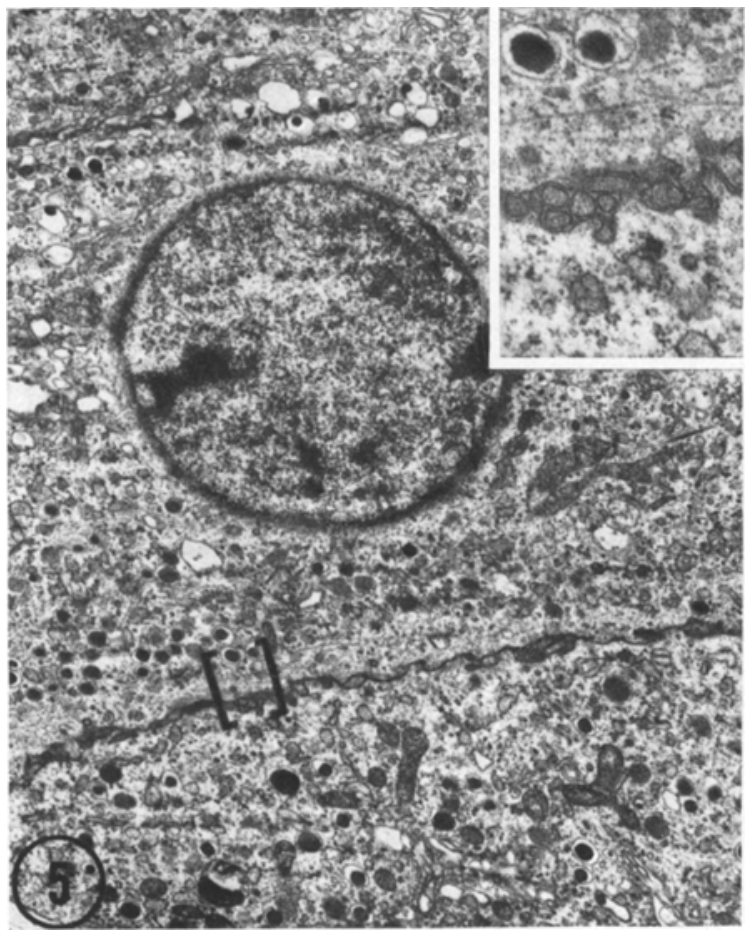

Fig. 5. Two beta cells attached by interdigitated cell membrane projections (brackets). $\times 6700$. The ultrastructural details are shown in the inset at higher magnification $\times 15700$. Ten days in culture

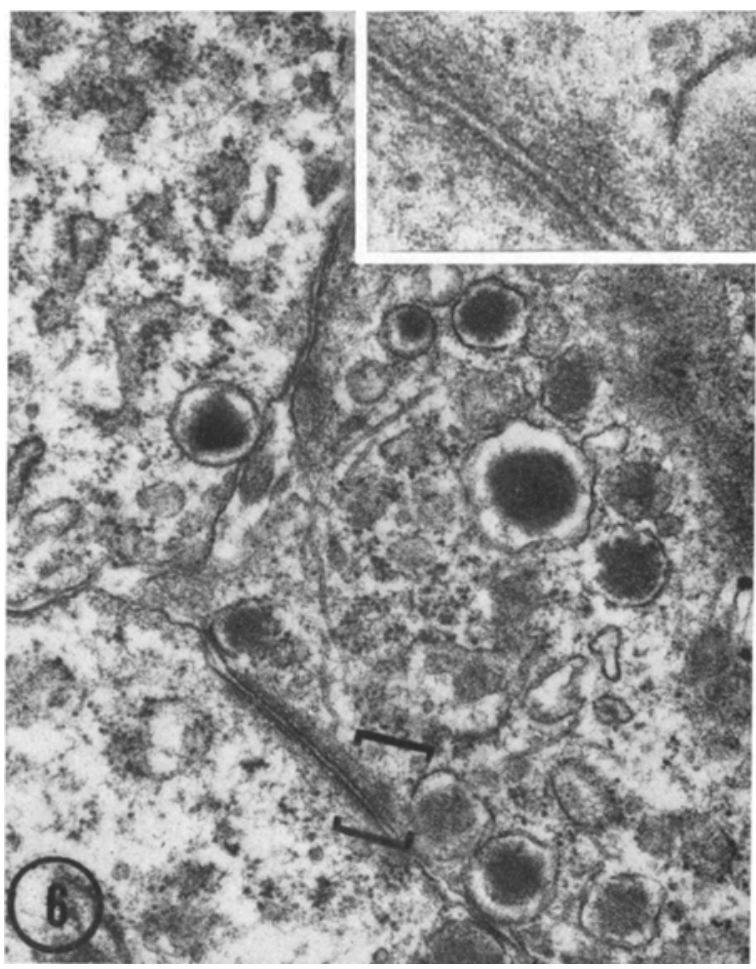

Fig. 6. Typical desmosomes with tonofibrils streaming into the cytoplasm of each cell $\times 34500$. The inset illustrated a part of a desmosome. $\times 80500$. Twelve days in culture 


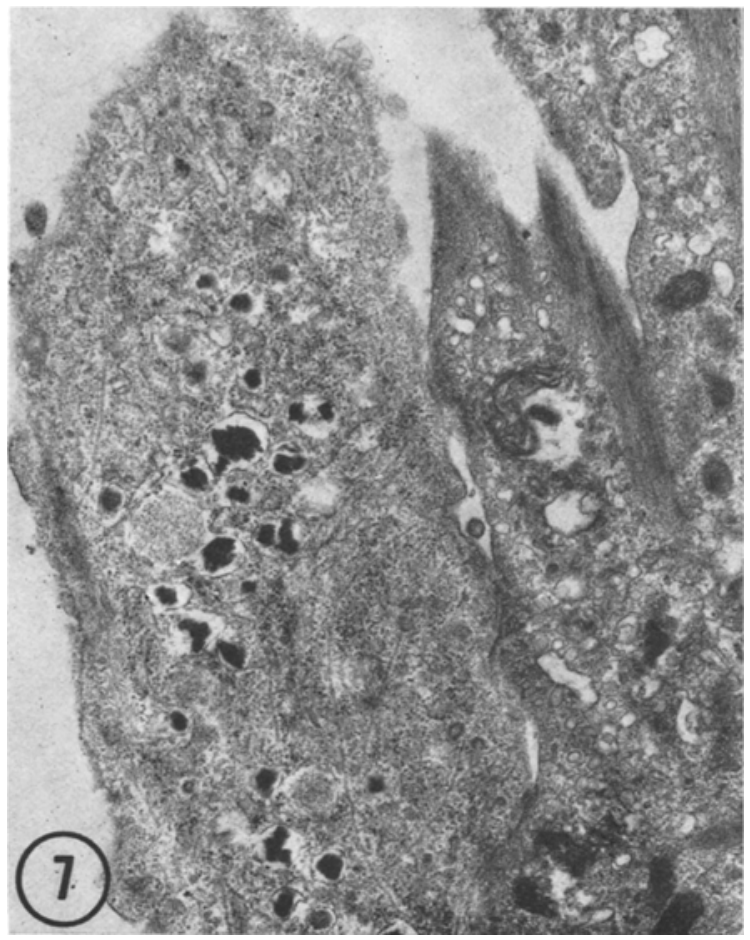

Orci et al. reported the formation of monolayer using whole neonatal rat pancreas and showed in vitro maturation and granulation of beta cells, with evidence of ultrastructural simplification and dedifferentiation of exocrine cells [26]. In addition, the authors have demonstrated in vitro insulin biosynthesis in this system [27]. Mc Evoy et al. [22] have also reported similar results using different techniques from the above authors. Chick $e t a l$. [5] reported the effects of high glucose concentration on beta cells in pancreatic monolayers cultured from neonatal rats, showing, by radioautographic studies, increased B-cell replication in the cultures maintained in high glucose concentration for 2 days. Tolbutamide also increased B-cell replication in contrast to glucagon, glucocorticoids and growth hormone, which in vitro produced no increase in

Fig. 7. Section through a beta cell containing numerous microtubules and crystalloid beta granules next to a fibroblastoid cell displaying profiles of dilated endoplasmic reticulum and bundle of parallel filaments. $\times 18700$. Twenty days in culture

Fig. 8. Two beta cells (B) alpha cells (A) and the socalled serotonin secreting cell (S). $\times 7300$. Six days in culture

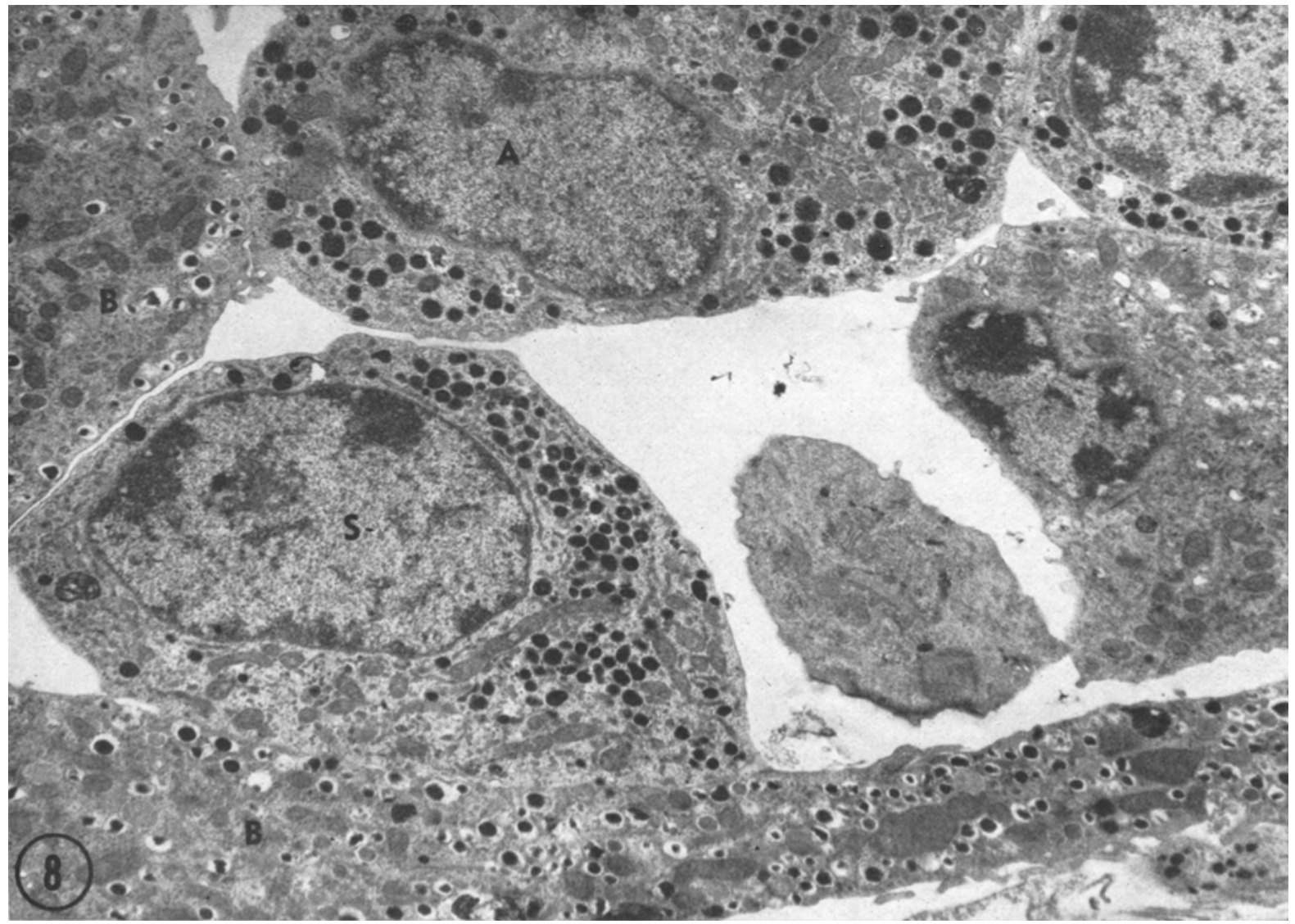


B-cell replication [6]. It is clear from our present study, that dispersed adult pancreatic islet cells maintained in tissue culture retain their morphological and functional properties compared with the non-cultured pancreatic islets. This technique appears suitable for the in vitro study of fully differentiated B-cells obtained from the adult rat under controlled tissue culture conditions. This preparation allows immediate and longterm morphological studies at the cellular level, with the additional possibility of morphological and functional correlation. Furthermore, since these cells in culture showed an increased amount of microfilaments and microtubules in their cytoplasm, it appears to be a good tool for further studies of these organelles per se as well as their relationship with intracytoplasmic granular movements.

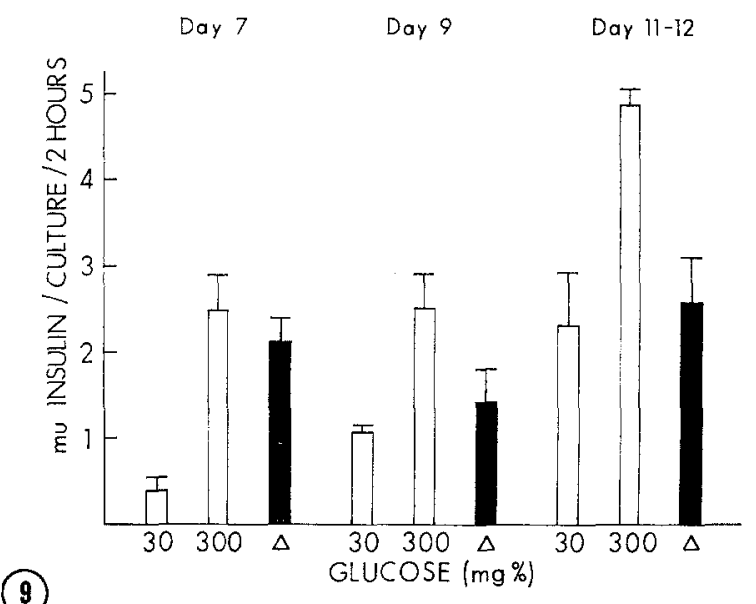

Fig. 9. Effect of glucose on insulin release of cultured pancreatic cells after varying days of culture. Each culture was exposed to $30 \mathrm{mg} \%$ glucose to obtain a basal level of insulin release followed by stimulation with $300 \mathrm{mg} \%$ glucose. $\Delta$ represents the net amount of insulin released due to exposure to $300 \mathrm{mg} \%$ glucose. In day 7 , $\mathrm{n}=5$; day $9, \mathrm{n}=3$ and day $11-12, \mathrm{n}=3 .(\mathrm{n}=$ number of separate experiments)

\section{References}

1. Anderson, A.: Monolayer culture of pancreatic islet cells. In: Falkmer, S., Hellman, B., Täljedal, I.B.: The structure and metabolism of the pancreatic islets, p. $73-80$. Oxford: Pergamon Press 1970

2. Andersson, A., Hellerström, C.: Metabolic characteristics of isolated pancreatic islets in tissue culture. Diabetes 21, 546-554 (1972)

3. Andersson, A., Hellerström, C., Peterson, B.: Phasecontrast microscopy of fresh and cultured pancreatic islet cells of guinea-pigs. Z. Zellforsch. 82, 110-117 (1967)

4. Buckley, T.K., Porter, K.R.: Cytoplasmic fibrils in living cultured cells. A light and electron microscope study. Protoplasma 64, 349-380 (1967)

5. Chick, W.L., Lauris, V., Flewelling, J.H., Andrews, K.A., Woodruff, J.M.: Effects of glucose on beta cells in pancreatic monolayer cultures. Endocrinology 92, 212-218 (1973)
6. Chick, W.L.: Beta cell replication in rat pancreatic monolayer cultures. Effects of glucose, tolbutamide, glucocorticoid, growth hormone and glucagon. Diabetes $22,687-693(1973)$

7. Goldman, R.D., Follet, E.A.C.: The structure of the major cell processes of isolated BHK-21 fibroblasts. Exp. Cell Res. 57, 263-276 (1969)

8. Gomori, G.: Aldehyde fuchsin, a new stain for elastic tissue. Amer. J. clin. Path. 20, 665-666 (1950)

9. Harris, A.K.: Cell surface movements related to cell locomotion. In: Locomotion of tissue cells, p. 5. Ciba Foundation Symposium. New York 14: Assoc. Seientific Publishers 1973

10. Hilwig, I., Schuster, S., Heptner, W., Wasielewski, E.V.: Über das Wachstum der Pankreaszellen von Säugetieren als Monolayer cultures. I. Züchtungsmethode, Morphologie und Insulingehalt. Z. Zellforsch. 103, 333-346 (1968)

11. Jönsson, L.E., Pontén, J., Thorell, J.: Long term production of insulin by adult rat pancreas in vitro. Diabetologia 2, 157-161 (1966)

12. Kostianovsky, M., Lacy, P.E., Greider, M.H., Still, M. : Long term (15 days) incubation of islets of Langerhans isolated from adult rats and mice. Lab. Invest. 27, 53-61 (1972)

13. Kostianovsky, M., Lacy, P.E., Codilla, R.: Technical procedure for obtaining and culturing cells of adult rat islets of Langerhans. Lab. Invest. 28, 389 (1973)

14. Lacy, P.E., Young, D.A., Fink, C.J.: Studies on insulin secretion in vitro from isolated islets of the rat pancreas. Endocrinology 83, 1155-1161 (1968)

15. Lacy, P.E., Kostianovsky, M.: Method for the isolation of intact islets of Langerhans from the rat pancreas. Diabetes 16, 35-39 (1967)

16. Lambert, A.E., Orci, L., Kanazawa, Y., Renold, A. E., Rouiller, Ch.: Control of endocrine function in organ cultures of fetal rat pancreas. In: Falkmer, S., Hellman, B., Täljedal, I.B.: The structure and metabolism of the pancreatic islets, pp. 81-85. Oxford: Paergamon Press 1970

17. Lambert, A.E., Blondel, B., Kanazawa, Y., Orci, L., Renold, A.E.: Monolayer cell culture of neonatal rat pancreas: Light microscopy and evidence for immunoreactive insulin synthesis and release. Endoerinology 90, 239-248 (1972)

18. Lambert, A.E., Vecchio, D., Gonet, A., Jeanrenaud, B., Renold, A.E. : Organ culture of fetal rat pancreas, effect of tolbutamide, glucagon and other substances. In: Butterfield, W.J.H., Van Westering, W.: Tolbutamide after 10 years, p. $61-82$. New York: Excerpta Medica Foundation 1967

19. Lambert, A.E., Junod, A., Stauffacher, W., Jeanrenaud, B., Renold, A.E.: Organ, culture of fetal rat pancreas. I. Insulin release induced by caffeine and by sugars and some derivatives. Biochim. biophys. Acta (Amst.) 184, 529-539 (1969)

20. Lambert, A.E., Jeanrenaud, B., Renold, A.E.: Enhancement by caffeine of glucagon-induced and tolbutamide-induced insulin release from isolated fetal pancreatic tissue. Lancet 1967 1, 819-820

21. Macchi, I.A., Blaustein, E.H.: Cytostructure and endocrine function of monolayer cultures of neonatal hamster pancreas. Endocrinology 84, 208-216 (1968)

22. McEvoy, R.C., Hegre, O.D., Leonard, R.J., Lazarow, A.: Fetal rat pancreas differentiation of the acinar cell component in vivo and in vitro. Diabetes $\mathbf{2 2}$, $584-589(1973)$

23. Moskalewski, S.: Isolation and culture of the islets of Langerhans of the guinea pig. Gen. comp. Endocr. 5, $342-353(1965)$

24. Moskalewski, S.: Comparison of cultured and transplanted islets of the guinea pig. In: Falkmer, S., Hellman, B., Täljedal, I.B.: The structure and 
metabolism of the pancreatic islets, p. $69-72$. Oxford: Pergamon Press 1970

25. Murrel, L.R.: Mammalian pancreatic islet tissue in organ culture. I. Methods of culture and in vitro histogenesis. Exp. Cell Res. 41, 350-364 (1966)

26. Orei, L., Like, A.A., Amherdt, M., Blondel, B. Kanazawa, Y., Marliss, E.B., Lambert, A.E., Wollheim, C. B., Renold, A.E. : Monolayer cell culture of neonatal rat pancreas: An ultrastructural and biochemical study of functioning endocrine cells. $J$. Ultras. Res. 43, 270-297 (1973)

27. Orei, L., Lambert, A.E., Kanazawa, Y., Amherdt, M., Rouiller, C.H., Renold, A.E.: Morphological and biochemical studies of $B$ cells of fetal rat endocrine pancreas in organ culture. Evidence for (Pro) insulin biosynthesis. J. Cell Biol. 50, 565-582 (1971)

28. Peterson, B.: Isolation and characterization of different types of pancreatic islet cells in guinea-pigs. Acta endocr. (Kbh) 53, 480-488 (1966)

29. Robbins, E.: Rapid embedding of cell culture monolayers and suspension. In: Kruge, P.F., Patterson, M.K., Jr.; Tissue culture: Methods and application pp. 437-439. New York: Academic Press 1973

30. Scharp, D.W., Kemp, Ch.B., Knight, M., Ballinger, W.F., Lacy, P.E.: The use of ficoll in the preparation of viable islets of Langerhans from the rat pancreas. Transplantation 16, 686-689 (1973)

31. Scott, H.R.: Rapid staining of beta cell granules in pancreatic islets. Stain Technol. 27, 267-268 (1952)

32. Vecchio, D., Gonet, A.E.: Culture d'organe de pancreas foetal de rat. I. Effects du glucose d'autres composants du milieu de culture et d'un sulfamide hypoglycemiant, Helv. physiol. Acta 25, 103-122 $(1967)$

33. Westman, J., Andersson, A., Peterson, B., Hellerström, C.: Ultrastructure of monolayer cultures of pancreatic islet cells. Acta diabet. lat. 7, 557-589 (1970)

34. Wright, P.H., Malaisse, W.J., Reynolds, I.J.: Assay of partially neutralized guinea pig anti-insulin serum. Endocrinology 81, 226-234 (1967)

Dr. M. Kostianovsky

Veterans Administration Hospital

Dept. of Pathology

Washington University

St. Louis, Missouri 63110

USA 